\title{
The Development Of Village-Owned Enterprises In Bogor Regency: Policy Evaluation Perspective
}

\author{
Sri Lestari ${ }^{1}$, Tatang Sudrajat ${ }^{2}$ \\ \{Srilestari.tari61@gmail.com ${ }^{1}$, id.tatangsudrajat@gmail.com $\left.{ }^{2}\right\}$ \\ STIA Bagasasi Bandung ${ }^{1}$, Universitas Sangga Buana Bandung ${ }^{2}$
}

\begin{abstract}
Various problems are faced by the government, related to the demographic fact that the majority of the population resides in rural areas. Severals form of public interest has been determined by the state, including the policy of establishing a Village Owned Enterprise (BUM Desa). The issuance of UU No. 6 of 2014, PP No. 43 of 2014, and Permen DPDTT Number 4 of 2015 is juridical basis, by establishing operational policies for the establishment of BUM Desa. This research aims to evaluate the substance of policies in Bogor Regency related to BUM Desa. Normative juridical research methods and literature review show that there is a relationship between the local government as a policymaker and the policy environment as well as a hierarchical relationship with policymakers regarding BUM Desa at the national level. In Bogor Regency, this local policy is in the form of Perda No. 6 of 2015 and Perbup No. 79 of 2018. There are several policy substances that are included in bad policies, namely those that are unclear, incomplete, ambiguous, and contradictory. It is necessary to improve the two local policy products.
\end{abstract}

Keywords: evaluation; policy; public policy; village-owned enterprises.

\section{Introduction}

Demographic-geographically, most of the people live in the countryside, with the main livelihood as farmers, most of whom still live in poor socio-economic terms. The government since President Soekarno until now, in realizing one of the functions of the state as stated in the fourth paragraph of the state constitution, namely promoting public welfare, has established various policies, programs and actions to improve the welfare of these rural residents. What the government has done is the realization of the constitutional mandate so that it becomes a solid foundation because it is written explicitly in paragraph 2 of the Preamble to the 1945 Constitution as a manifestation of 
national ideals. The realization of a just and prosperous society, especially for rural communities, is essentially one of the visions of the Indonesian nation and state.

This constitutional mandate is operationally translated into various laws and regulations, especially those related to rural community development. For this reason, the state and its main organs, namely the government at various levels and all of its apparatuses, establish various plans and implement national development programs. The aim is to answer various challenges and problems faced by rural communities.

One of the state's political decisions that aims to provide guarantees for their welfare is the issuance of Law (UU) Number 6 of 2014 concerning Villages [1], in which there are regulations regarding Village Owned Enterprises (BUM Desa). This political decision was later elaborated in PP Number 43 of 2014 concerning Implementing Regulations of Law Number 6 of 2014 concerning Villages. Operationally, to fulfill the mandate of Article 142 of the government regulation, the Minister of Villages, Development of Disadvantaged Regions and Transmigration (PDTT Village) issued Ministerial Regulation (Permen Desa PDTT) Number 4 of 2015 concerning the Establishment, Management and Management, and Dissolution of Village-Owned Enterprises [2]. The issuance of these three state and government political decisions is something important as a tangible manifestation of the state/government's concern and responsibility for the welfare of the community.

As part of the state administration system, based on PP No. 43 of 2014 [3], district regulations and regent's regulations are formed in districts, thus providing a more operational juridical basis for the establishment and development of this BUM Desa. From a public policy perspective, the issuance of various regulations in this area is clearly an entry point, a tangible manifestation of the solid framework of relations and the role of the district government as a supporter of the Unitary State of the Republic of Indonesia, and is a manifestation of public policy.

From the perspective of the public interest, the presence of these regulations is a form of public policy. According to Gerston, public policy is the combination of basic decisions, commitments, and actions made by those who hold or influence government positions of authority [4]. Posts et al. put it forward as a plan of action undertaken by government officials to achieve some broad purpose affecting a substantial segment of a nation's citizens [5]. In line with the Post's emphasis on its definition of a plan, Lawrence and Weber argue that public policy is a plan of action undertaken by government officials to achieve some broad purpose of affecting a substantial segment of a nations citizens [6].

With the presence of these various regulations, policy makers in the regions have clear guidelines so that they will be able to facilitate the achievement of the policy objectives of establishing this BUM Desa. As a product of the political and governmental processes, these three state/government regulations regarding Village-owned Enterprises are of course published based on an in-depth and comprehensive study of multidimensional rural problems. In Bogor Regency, to realize this, Regional Regulation (Perda) Number 6 of 2015 concerning Villages [7] and Regent's Regulation (Perbup) Number 79 of 2018 concerning the Establishment, Management, Management and Dissolution of Village-Owned Enterprises [8] have been issued. The issuance of these two local government policies is certainly a real response to the socio-economic realities of rural residents in Bogor Regency, which has a population of 4,699,282 people, spread over 435 villages, of which $7.69 \%$ are below the poverty line [9]. 
Research Hidayah et al. shows that Bogor Regency is active in the formation of BUM Desa, because out of 416 villages there are 380 villages that already have BUM Desa [10]. To realize the goal of establishing BUM Desa, various aspects need to be evaluated. Hidayah's research shows that the implementation and establishment of the BUM Desa program as a whole has not been maximized [11]. Various challenges and problems were faced in the development of BUM Desa, including those related to capital, knowledge and management of the board, as well as the insight of the village community [12].

The effectiveness of a policy depends, among other things, on the quality of the substance of the policy that has been established. Therefore, it is important to conduct a policy evaluation that focuses on the substance of the policy (policy content) that has been determined by the government as an integral part of the overall public policy cycle.

This study aims to elaborate and evaluate the substance of public policies regarding the organizational aspects of BUM Desa, in the form of UU Number 6 of 2014[1], PP Number 43 of 2014[3], Permen Desa PDTT Number 4 of 2015[2], Perda of Bogor Regency Number 6 of 2015[7], and Perbup Bogor Number 79 of 2018[8].

\section{Literature Review}

\subsection{Business Organizations and Village Owned Enterprises}

The existence of the organization will not be separated from human activities as homo socius who cooperate, regardless of shape, size and type. Narayanan and Nath mention there are several reasons why organizations are important entities. First, organizations are pervasive through the modern world. Second, people working alone can do simple tasks. It is only through working together in an organization that complex tasks can be performed. Third, when human effort is organized effectively, its results in higher productivity than would be possible with an unorganized collection of individuals [13]. Thus it is clear the important position of the organization in modern society to get the results of human work more effectively.

In this regard, Victor A. Thompson stated that the organization is a highly rationalized and impersonal integration of a large number of specialists cooperating to achieve some announced specific objectives [14]. Organization according to Frances Westley quoted by Rosenbloom et al is a series of interlocking routines, habituated action patterns that bring the same people together around the same activities in the same time and places [15]. Robbins suggests that the organization is 'a consciously coordinated social entity, with a relatively identifiable boundary, that functions on a relatively continuous basis to achieve a common goal or set of goals' [16]. In Siagian's formulation, organization is 'any form of alliance between two or more people who work together for a common goal and are formally bound in an alliance, where there is always a relationship between a person/group of people called the leader and another person/group of people called subordinates' [17].

Organization is a social unit of a group of people who interact with each other according to a certain pattern so that each member of the organization has their respective functions and duties, which as a unit have certain goals, and have clear boundaries so that they can be clearly separated from their environment [18]. Narayanan and Nath [13] define it as an arena where human beings 
come together to perform complex tasks so as to fulfill common goal(s). Some of the characteristics of organizations according to James G. March and Herbert A. Simon as quoted by Henry include that organizations are purposeful, complex human activities, have specialized and limited goals, are characterized by sustained cooperative activity, provide services and products to their environment, and are dependent upon exchanges with their environment [14]. One of the five basic elements of an organization according to Henry Mintzberg is the operating core, namely employees who perform the basic work related to the production of products and services [16].

Business consists of all profit-seeking activities and enterprises that provide goods and services necessary to an economic system [19]. With more emphasis on the existence of an organization, Griffin and Ebbert argue that business is an organization that provides goods and services that are then sold to earn profits [20]. In line with that, Pride, Hughes and Kapoor define business as the organized effort of individuals to produce and sell, for a profit, the goods and services, that satisfy society's needs. To be successful, a business must perform three activities. It must be organized, it must satisfy needs, and it must earn a profit [21].

Talcot Parsons as quoted by Narayanan and Nath mentions that there are four types of organizations, namely 'production organization, political organization, integrative organization, and pattern maintenance organization'. It was further stated that production organizations are organizations that make things or products. [13]. Based on the purpose of its establishment, BUM Desa can be categorized as a production organization, because it provides something that is beneficial to the community, especially in rural areas. This is in accordance with the provisions of Article 1 Number 1, Article 2 and Article 3 of the PDTT Village Regulation Number 4 of 2015[2], which relates to the boundaries/definition of BUM Desa, the aims and objectives of establishing BUM Desa. Based on the characteristics of the organization as stipulated in several government regulations, it is clear that this BUM Desa is classified as a business organization.

\subsection{Public Policy}

The political decisions of the state and government regarding BUM Desa are factually inseparable from public administration and public policy. Public policy is the dynamics of public administration, because the real manifestation of achieving state goals is real actions or programs carried out by the state for the public interest. Public administration according to Dwight Waldo is "the organization and management of man and material to achieve the purpose of government" [22]. The socio-economic welfare of rural communities, which has always been a concern of the government, relates to one of the goals of the state, one of which is the policy of establishing BUM Desa.

Related to that, Ranson and Stewart mention that government in interacting with the community perform several important roles. They can be conceptualized as a sustaining role, a maintenance role, a responsive role and a developmental role [23]. It is within this framework that the role of public policy will give its own color and label to the public administration of a country. Therefore, it is understandable that public administration scholars refer to this public policy as one of the prime dimensions of state administration.

This policy 'is one of the strategic aspects or dimensions of the six strategic dimensions or the one that most determines the dynamics of public administration, namely in the form of responding correctly to the needs, interests and aspirations of the community in the form of decision making or 
public policy' [24]. There is not a single segment of life that is separated from the attention of the state administration. Public administration is an activist part of government. It is a means by which government seeks to intervene in aspects of the economy, society and polity [15]. Public policies, especially those that can be implemented effectively, will have a positive impact on the government's reputation. It is in this context that it can be understood when some public administration experts define public administration as a process for implementing public policy.

In fact, citizens in all parts of the world will be faced with various kinds of problems that they cannot always solve on their own. The problem that was actually felt then became a broad public concern, and became the government's concern and agenda. In the next stage, there are a series of political and/or administrative processes, which through government decision-making give birth to actual actions/programs for the public interest, so that public policies are born.

With a focus on government choices, according to Dunn, public policies are 'long series or more less related choices (including decisions not to act) made by governmental bodies and officials, are formulated in issue areas which range from defense, energy and health to education, welfare. and crime control' [25]. MacRae Jr. and Wilde defines it as 'a policy made by government. Policy is a chosen course of significantly affecting large numbers of people'[26]. Another public policy expert, Anderson said that public policies are those policies developed by governmental bodies and officials [27]. It appears that the state or government is very strategic in the formation of this public policy.

This is in line with Michael's view that the state plays an important and decisive role in the formation and implementation of public policy. It is the state that provides the basis for collective decision making, the application and enforcement of those decisions, and the means for changing or altering others [28]. According to Gerston, there are five components of public policy, namely issues, actors, resources, institutions and the level of government [4]. In order to fully understand public policy, it can be identified by what Anderson calls the policy categories, namely policy demands, policy decisions, policy statements, policy outputs and policy outcomes [27].

Thus, public policy is a series of decisions made by state/government officials and/or institutions that previously involved various parties and were followed by concrete actions in accordance with the authority they had to deal with public problems. In the context of BUM Desa, one of the forms or forms of public policy is UU Number 6 of 2014[1], PP Number 43 of 2014[3], Permen Desa PDTT Number 4 of 2015[2], Perda of Bogor Regency Number 6 of 2015 [7] and Perbup of Bogor Number 79 of 2018 [8]. In the current regional government system, the position and existence of regional regulations, regional head regulations and regional head decisions are regional policies as stated in Law Number 23 of 2014 concerning Regional Government. It is said to be a public policy because everything is born from the authority of public institutions in this case the DPR, the President, the Minister and the Regional Government of Bogor Regency to deal with public problems with regard to various demands and expectations of the public regarding the needs and demands of rural communities regarding their socio-economic welfare.

\subsection{Policy Evaluation}

By using the process model to gain a complete understanding of public policy, it is clear that the policy cycle is a multidimensional process and involves many actors, both community and state/government institutions. One of the stages is policy evaluation, which according to Gerston 
'assesses the effectiveness of a public policy in terms of its perceived intentions and results' [4]. This stage is defined by Jones as 'an activity designed to judge the merits of government programs or processes. It varies in the specification of criteria, the techniques of measurement, the methods of analysis, and the forms of recommendation' [29].

Policy evaluation is an integral part of the public policy cycle which plays a very important role in determining the level of achievement of organizational policy or program targets. This evaluation phase is strategic because in reality it is not necessarily the final target of a public policy or program that will be implemented effectively. Various ideal expectations as formulated at the time of policy determination, the level of achievement will be known by this evaluation stage. In other words, comprehensive information on policy performance is very important for policy makers and policy implementers as a medium for policy improvement in the future.

\section{Research Methods}

This research uses a normative juridical method combined with literature study and policy evaluation. According to Marzuki [30] it is classified as legal research, or normative legal research or library law which is carried out by examining library materials or secondary data [31]. Referring to Howlet and Ramesh, process evaluation is one of five types of administrative evaluation, namely 'examine the organizational methods, including rules and operating procedures, used to deliver programs' [32]. One type of policy analysis is studies of policy content, in which analysis seek to describe an explain the genesis and development of particular policies [33]. Research is conducted on information that is documented in the form of regulations so that it is commonly known as document analysis research or content analysis.

In accordance with the purpose of the research, the researcher focused on all statutory documents regarding or related to BUM Desa, as well as secondary data sourced from other relevant documents. For this purpose, researchers use documentation techniques. The documents that are the center of attention for this research are the Perda of Bogor Regency Number 6 of 2015 [7] and the Perbup Bogor Number 79 of 2018 [8], as well as other related documents, namely UU Number 6 of 2014[1], PP Number 43 of 2014 [3] and the Permen Desa PDTT Number 4 of 2015 [2].

\section{Results And Discussion}

\subsection{BUM Desa Profile, Hierarchy and Policy Context}

From the perspective of public administration and public policy, as stated by Anderson that in the form of public policy as something that is actually carried out by the government, it must have a legal aspect so that it is coercive for its implementation [27] and Gerston that the levels of government that address issues [4], the regulation regarding BUM Desa is contained in state/government regulations at various levels. Permen Desa PDTT Number 4 of 2015[2], Perda Bogor Regency Number 6 of 2015[7], and Perbup Bogor Number 79 of 2018 [8]are the formal legalities of public policy. This is in line with what Stillman II stated that one of the identities of public administration is rooted in the law as well as concerned with carrying out laws [34]. In 
addition, because the substance of the regulation it contains regarding the public interest in the form of the fact that there are still high hopes for rural communities to get better socio-economic welfare.

The presence of UU Number 6 of 2014 on January 15, 2014 and consisting of 122 articles, revoked and declared that Article 200 to Article 216 regarding villages contained in Law Number 32 of 2004 concerning Regional Government was no longer valid. With regard to BUM Desa, it is regulated in Articles 87 to 90. PP Number 43 of 2014 which was issued on May 30, 2014, consists of 159 articles, revoking and declaring that PP Number 72 of 2005 concerning Villages is no longer valid. Substances relating to BUM Desa are regulated in Articles 132 to Article 142. The stipulation of Permen Desa PDTT Number 4 of 2015 on February 13, 2015 which consists of 35 articles, is a regulation stating that the provisions regarding BUM Desa contained in Permendagri Number 39 of 2020 concerning Village Owned Enterprises are no longer applicable.

Perda of Bogor Regency Number 6 of 2015 as a replacement for this Perda Number 9 of 2006, was enacted on August 14, 2015 and consists of 286 articles. As a legal basis, among others, it mentions UU Number 6 of 2014, PP number 43 of 2014, and the Permen of Desa PDTT Number 4 of 2015, and has been amended by Regional Regulation Number 6 of 2018. The substance of the regulation of BUM Desa is contained in Article 248 to Article 263. The mention of the three central government regulations is something that is very appropriate, because the inclusion of certain legal bases in a policy product in the regions provides a solid foundation of juridical legitimacy.

Perbup Bogor Number 79 of 2018 which was stipulated on October 26, 2018 which consists of 53 articles, is a follow-up to the provisions of Article 263 of the Perda of Bogor Regency Number 6 of 2015. This regulation, among others, mentions as the legal basis three regulations from the central government, UU Number 6 of 2014, PP Number 43 of 2014 and Permen of Desa PDTT Number 4 of 2015.

Adopting Bromley's view [35], Law Number 6 of 2014, several other regulation relating to BUM Desa and Government Regulation Number 43 of 2014 are at the policy level, further elaborated by the Minister of Villages PDTT in Ministerial Regulation Number 4 of 2015 which are at the organizational level. In Bogor Regency this is further elaborated in Perda Number 6 of 2015 and Perbup Number 79 of 2018 which are both at the operational level.

From the perspective of the hierarchy of public policies, the presence of Law Number 6 of 2014 is a guideline for the policy of establishing BUM Desa which is determined by state administrators at the national level and binds all stakeholders. In addition, it is also in line with what was stated by Gerston regarding the level of government, as well as the principle of hierarchy as regulated in Article 7 paragraph (2) of Law Number 12 of 2011 concerning the Establishment of Legislation. The point is that all products of laws and regulations must be consistent with the principle of hierarchy that regulations at a higher level must serve as a guide for the formation of regulations below them.

The stipulation of PP Number 43 of 2014 is something that is imperative refer to the terms of several articles in UU Number 6 of 2014. The fact that there are replacements or amendments to several laws, regulations, and regional regulations shows that there is an interdependence relationship between state/government institutions and their environment. This is in line with what Robert Eyestone stated that public policy is "the relationship of a government unit to its environment"[27].

This is in line with what Dunn stated about the policy system, A Policy System, or the overall institutional pattern within which policies are made, involving interrelationship among three 
elements: public policies, policy stakeholders, and policy environments.' [25]. The issuance of UU Number 6 of 2014 and several other laws related to rural areas, PP No. 43 of 2014, Permen Desa PDTT No. 4 of 2015, Perda of Bogor Regency No. 6 of 2015, and Perbup of Bogor No. 79 of 2018, clearly is basically a form of public policy. This is a response to the policy environment in the form of growing awareness and demands of rural communities for the form of state/government services regarding their socio-economic conditions. On the other hand, the issuance of various regulations will affect the policy environment.

In the context of an integral public policy system regarding BUM Desa, the national/central government acts as a legislator, government regulations and ministerial regulations as a policy maker, the district government as a policy implementor as well as a policy maker that is more technical in nature and operational. BUM Desa managers and community members are located as policy targets.

The issuance of all these regulations is due to the role of stakeholders in the policy of establishing BUM Desa, which consists of state/government institutions and actors (governmental actors) and actors in the community (nongovernmental actors). State actors, namely state / government officials, presidential institutions, legislators, government bureaucrats and actors in the community, including entrepreneurs / business people, all have their own elements called policy stakeholders . The position of policy makers who are at the level of legislative and executive institutions at the center and regions, which in the context of the policy system is part of this political system, their powers and obligations are regulated in various laws that govern them. Between the regulations for the development of BUM Desa as a public policy and the stakeholders of this policy, there is a relationship of mutual influence.

Schematically, this can be visualized as follows:

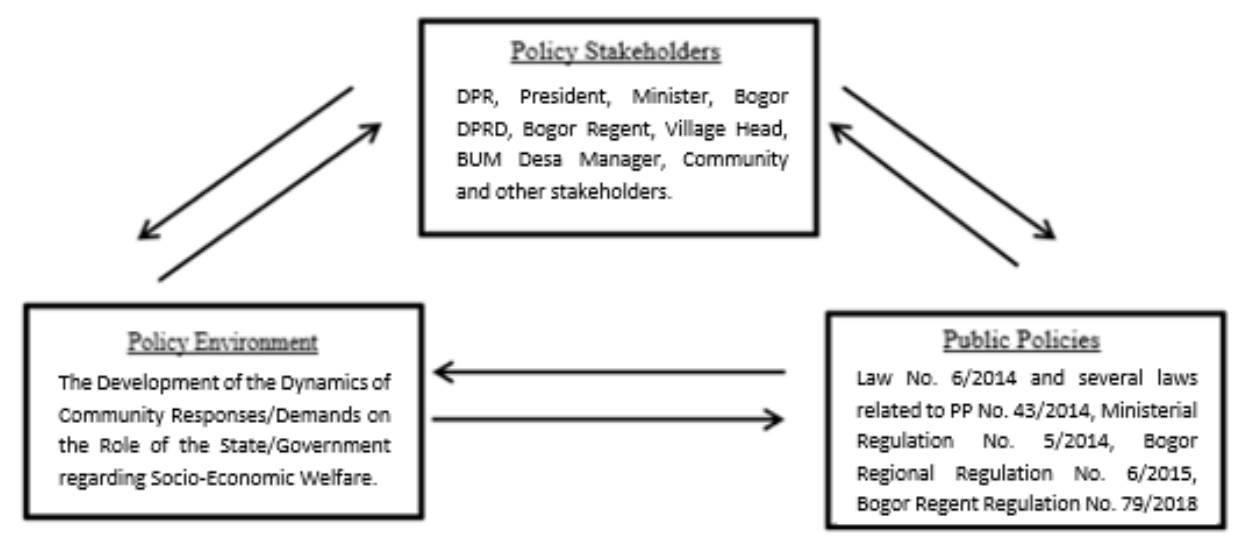

Fig. 1. BUM Desa Regulations in the Policy System Source : Adaptation from Dunn [25]

Referring to and adapting the views of Bromley [35], the existence of UU Number 6 of 2014, several related laws, and PP Number 43 of 2014 are at the policy level, while the Permen Desa PDTT Number 4 of 2015 is at the organizational level. At the operational level, there are Perda of 
Bogor Regency Number 6 of 2015 and Perbup Bogor Number 79 of 2018. In their implementation, all of these policy products lead to patterns of interaction that take place at the level of implementing policies and with the public or community members as policy targets. In fact, of course, there will be many responses from the public and other BUM Desa stakeholders to the village government and BUM Desa managers in various forums. One of these inputs relates to the obstacles and problems when forming BUM Desa and when the managers carry out their duties. In this regard, it is very important to have an objective evaluation of the implementation aspects including input from the stakeholders of this program as a basis for improving future policies. Another aspect that must also receive attention is the evaluation of the substance of the policy, because a good policy is the initial capital for the effective implementation of the policy for establishing BUM Desa.

Schematically, the hierarchy and policy process for the establishment of BUM Desa can be visualized as follows:

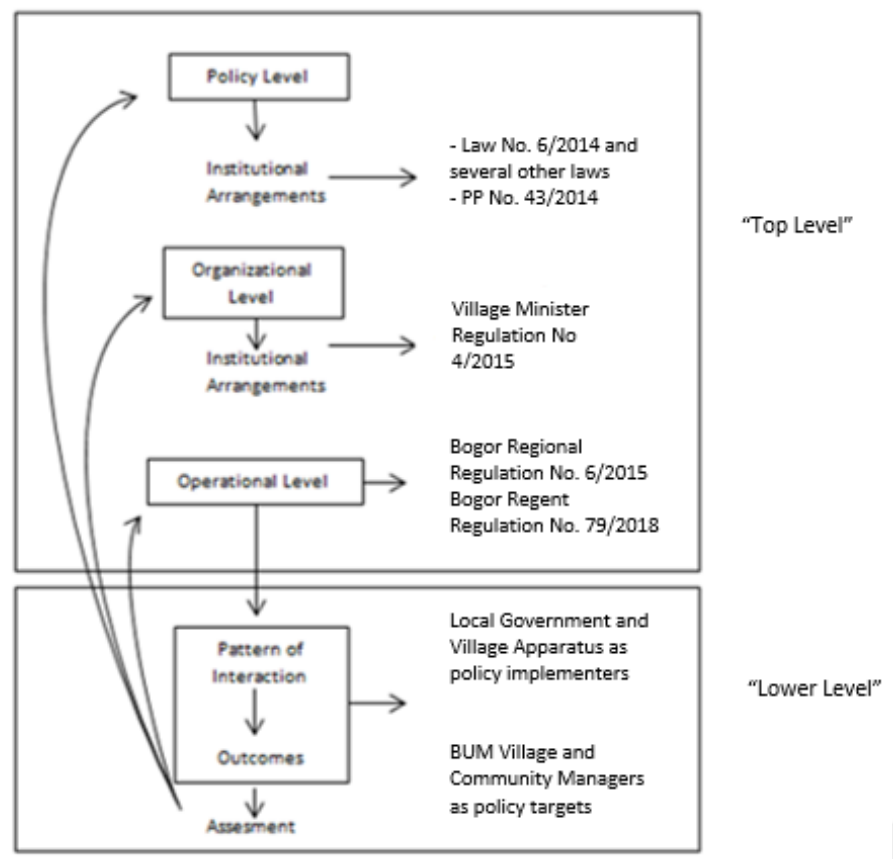

Fig. 2. BUM Desa Policy Hierarchy Source : Adapted from Bromley [35]

From a public policy perspective, as stated by Anderson that every decision or policy made by public officials must be based on law, the Perda of Bogor Regency Number 6 of 2015, the juridical basis regarding BUM Desa refers to Law Number 6 of 2014, PP Number 43 of 2014, and Permen Desa PDTT Number 4 of 2015. In addition, there are several other regulations related to the establishment of BUM Desa which are the juridical basis, including Permendagri Number 111 of 2014 concerning Technical Guidelines for Regulations in Villages, Permendagri Number 113 of 2014 concerning Village Financial Management, and Permen Desa PDTT Number 2 of 2015 
concerning Guidelines for Order and Decision Making Mechanisms for Village Deliberations.

Likewise, Perbup Bogor Number 79 of 2018, which in its preparation was based on Article 263 of Regional Regulation Number 6 of 2015. In addition, it is also based on several related laws and regulations, including Law Number 1 of 2013 concerning Microfinance Institutions, Law Number 23 of 2014 concerning Regional Government, and Permen Desa DTT Number 4 of 2015.

\subsection{Substance of BUM Desa Policy}

The substance of the policy setting for the establishment of BUM Desa includes the purposes, objectives and organizational structure of this institution, which are listed in several state/government regulations. According to Article 2 of the Permen Desa PDTT Number 4 of 2015, the purpose of establishing BUM Desa is an effort to accommodate all activities in the economic sector and/or public services managed by the Village and/or inter-Village cooperation. The objective as regulated in Article 3 is to improve the Village economy; optimize Village assets to be useful for Village welfare; improve community efforts in managing the village's economic potential; develop a business cooperation plan between villages and/or with third parties; create market opportunities and networks that support the public service needs of citizens; create job opportunities; improve the welfare of the community through the improvement of public services, growth and equity of the Village economy; and increase Village community income and Village Original Income.

From a public policy perspective, the existence of arrangements regarding these aims and objectives is very appropriate and important. This is in line with what Anderson put forward that one of the concepts of public policy is purposive or goal oriented action rather than random or chance behavior is our concern [27]. In the context of BUM Desa as an organization, according to Siagian, the existence of clear organizational goals that can be accepted and understood by everyone in the organization is one of the characteristics of a good organization [17]. The regulation in the PDTT Village Regulation becomes a guide for policy implementers in the region when setting more operational policies.

In UU Number 6 of 2014 [1] there are four articles regarding BUM Desa, but not specifically related to its organization. This should be regulated although not necessarily in detail, so that it becomes a reference when translated into more operational policies.

Several characteristics of the BUM Desa organization appear as regulated in several regulations, as follows :

a. The BUM Desa management organization based on Article 132 paragraph (3) of PP Number 43 of 2014, is separate from the village government, which structurally consists of at least advisors and operational implementers. Referring to Article 134, this institution is tasked with administering and managing BUM Desa in accordance with the articles of association and by-laws. Firmness on the term "separate" is a very important clause for the realization of a healthy organization. Agunggunanto et al's research shows that the problems of BUM Desa include aspects of capital, resource aspects and institutional aspects (2016: 77).

b. The form of BUM Desa organization may consist of business units that are legal entities as referred to in Article 7 paragraph (1) of the Permen Desa PDTT. A business unit that is a legal entity can be a business institution whose share ownership comes from the village 
BUM and the community. The firmness of this provision provides legal and organizational certainty when operational implementers will carry out their duties.

c. Referring to Article 9 of the Permen Desa PDTT Number 4 of 2015, the BUM Desa management organization is separate from the village government organization, whose composition consists of advisors, operational implementers and supervisors, as regulated in Article 10 paragraph (1). The advisor's obligations are regulated in Article 11 paragraph (2), while the authority is stated in paragraph (3). Firmness regarding the separation from village government organizations is one of the important organizational characteristics regulated in the policy for establishing this BUM Desa.

d. Based on Article 12 paragraph (1), the task of the operational executor is to administer and manage BUM Desa in accordance with the articles of association and by-laws. Regarding the obligations listed in paragraph (2), namely implementing and developing BUM Desa so that it becomes an institution that serves the economic needs and/or public services of the Village community; explore and utilize the potential of Village economic business to increase Village Original Income; and collaborate with other Village economic institutions. The authority as referred to in paragraph (3) is to make financial reports of all BUM Desa business units every month; make reports on the progress of activities of BUM Desa business units every month; provide reports on the development of BUM Desa business units to the Village community through Village Consultations at least 2 (two) times in 1 (one) year. Firmness regarding the duties and obligations of operational implementers as the operating core in implementing the policy for establishing BUM Desa is very important to be regulated in government regulations.

e. Referring to the Perda Bogor Regency Number 6 of 2015 Article 249 paragraph (3), the BUM Desa management organization is separate from the village government organization, whose composition as referred to in paragraph (4) consists of at least advisors and operational implementers. Firmness about the separate structure of the village government organization is very important, to ensure that there is no overlap in the management of organizational tasks and authorities.

f. As stated in Article 250 paragraph (1), the advisor's job is to supervise and provide advice to operational implementers. His authority as stated in Article 250 paragraph (2) is to ask for an explanation from the operational executive regarding the management and management of village businesses. The regulation regarding the duties and authorities of the advisor as an organizational unit is very important, although the article does not stipulate its obligations.

g. The task of implementing operations according to Article 251 is to administer and manage BUM Desa in accordance with the articles of association and by-laws. Regulation on the duties of organizational organs is very important, although the article does not stipulate the authority and obligations.

There are some unclear/ambiguous provisions, namely :

a. In his position as an advisor as regulated in Article 11 paragraph (1) of the Permen Desa DTT Number 4 of 2015, the Village Head has the obligation as referred to in paragraph (2), namely to provide advice to the Operational Implementer in implementing the management of BUM Desa; provide advice and opinions on issues that are considered important for the management of BUM Desa; and controlling the implementation of BUM 
Desa management activities. His authority as referred to in paragraph (3) is to ask for an explanation from the Operational Executor regarding issues relating to the management of Village businesses; and protect Village businesses against things that can reduce the performance of BUM Desa. One of the duties of an advisor who can control BUM Desa activities gives the impression of overlap or confusion with the duties of other elements in the BUM Desa organizational structure, namely the existence of a supervisor.

b. Referring to Article 132 paragraph (5) of PP Number 43 of 2014, because of his position, the village head serves ex officio as an advisor to the BUM Desa management organization. His duties as regulated in Article 133 paragraph (1) are to supervise and provide advice to operational implementers in carrying out village business activities and management. His authority as regulated in Article 133 paragraph (2) is to ask for an explanation from the operational executive regarding the management and management of village businesses. In addition, the village head is also authorized to appoint and dismiss the operational executors of BUM Desa as stipulated in Article 132 paragraph (6). It appears that his duties as an advisor who, among other things, must carry out supervision will cause overlapping with other organizational elements, namely supervisors.

c. Article 250 paragraph (1) of Perda Number 6 of 2015 which states that the duties of advisors include, among others, supervising operational implementers in carrying out village business management and management activities, which is a confusion with the meaning of the advisory function being clearly different from the supervisory function.

There are contradictory provisions, namely :

a. Article 19 paragraph (1) of the Perbup Bogor Number 79 of 2018 states that advisors are held ex officio by the village head. Its is contrary to Article 18 paragraph (2) which states that the composition of the BUM Desa management in which there are advisors is chosen by the village community through deliberation village.

b. Article 19 paragraph (3) letter c of Perbup Number 79 of 2018 which states that one of the obligations of the advisor is to control the implementation of BUM Desa management activities. This is something that is contradictory because organizationally the advisory function is something that is fundamentally different from the control function.

c. Article 18 paragraph (2) of Perbup Number 79 of 2018 states that the composition of the BUM Desa management is chosen by the village community through village meetings. It is contrary to the provisions of Article 249 paragraph (6) of Regional Regulation Number 6 of 2015 which states that operational implementers are appointed and dismissed by the head village.

There are incomplete provisions, namely :

a. Article 23 paragraph (4) of Perbup Number 79 of 2018 does not regulate the duties, functions, obligations or authorities of supervisors, only mentions the obligation to hold general meetings to discuss the performance of BUM Desa and report the results of supervision to the Village Government. Affirmation of supervision carried out by supervisors as a fact finding activity for management by operational implementers is very important for the effective running of the BUM Desa organization.

b. In Article 251 of the Regional Regulation Number 6 of 2015, only the duties of the Operational Executor are regulated, while the powers and obligations as the operating core are not regulated. This is different from Article 250 which regulates the duties and 
authorities of BUM Desa advisors. Organizationally, the authority and obligations of organizational elements should be explicitly regulated.

c. In Article 23 of the Perbup Number 79 of 2018 there are no regulations regarding the duties/functions/authorities/responsibilities of BUM Desa supervisors, but only regulates their obligations, as stated in Article 23 paragraph (4). It should be in line with the regulations regarding the Operational Executor, as well as the duties, obligations and responsibilities.

d. In Article 23 paragraph (2) of Perbup Number 79 of 2018 only mentions the chairman as one of the elements of the BUM Desa supervisory structure, unlike the deputy chairman and secretary, each of whom is referred to as a member. This has the potential to cause over use of authority from a chairman who feels he is the superior of the vice chairman, secretary and members. This clarity is also very important regarding the role of the chairman, for example, at certain moments when he has to make decisions.

\section{Conclusion}

Rural communities are faced with various problems, especially socio-economic problems that require the involvement of the state/government to handle them. Attention to this problem, after going through a series of processes in the structure of infrastructure and political superstructure, is determined to be a public policy, including the establishment and development of BUM Desa. There is a close relationship between public administration, public policy and the establishment of BUM Desa as one of the content of public policy. Whereas public policy products regarding or relating to BUM Desa which include UU Number 6 of 2014, and several related laws, PP Number 43 of 2014, Permen Desa DTT Number 4 of 2015, Perda of Bogor Regency Number 6 of 2015, and Perbup of Bogor Number 79 of 2018, shows a levelering in the overall public policy order. There are three contradictory policy substances, four aspects that are incomplete/unclear, and three aspects that are ambiguous/unclear. For the effective implementation of the policy, it is necessary to improve some of these regulations.

\section{References}

[1] "UU Nomor 6 Tahun 2014 tentang Desa."

[2] "Permen Desa PDTT Nomor 4 Tahun 2015 tentang Pendirian, Pengurusan dan Pengelolaan, Pembubaran Badan Usaha Milik Desa."

[3] "PP Nomor 43 Tahun 2014 tentang Peraturan Pelaksanaan UU 6 Nomor Tahun 2014 tentang Desa."

[4] Gerston, L. N. Public Policy Making. Process and Principles. Third Edition. New York: E Sharpe, 2010.

[5] Post, J. E. et al. Business and Society. Corporate Strategy, Public Policy, Ethics. Boston: Irwin McGrawHill, 1999.

[6] Lawrence A. T. and W. James, Business and Society. Stakeholders, Ethics, and Public Policy. New York: McGraw-Hill International Edition., 2014.

[7] "Perda Kabupaten Bogor Nomor 6 Tahun 2015 tentang Desa."

[8] "Perbup Bogor Nomor 79 Tahun 2018 tentang Pendirian, Pengurusan, Pengelolaan dan Pembubaran Badan Usaha Milik Desa."

[9] Badan Pusat Statistik, "Kabupaten Bogor Dalam Angka." 2015.

[10] Hidayah U. et al, "Optimalisasi Unit Usaha BUMDES Harapan Jaya Berdasarkan Potensi Lokal Di Desa Pagelaran,” J. Benefita, vol. 5, no. 1, 2020.

[11] Hidayah U. et al, "Evaluasi Badan Usaha Milik Desa : Studi Kasus BUM Desa Harapan Jaya Desa 
Pagelaran Kecamatan Ciomas Kabupaten Bogor,” JSHP, vol. 3, no. 2, 2019.

[12] Agunggunanto E. Y. et al, "Pengembangan Desa Mandiri Melalui Pengelolaan Badan Usaha Milik Desa," JDEB, vol. 13, no. 1, 2016.

[13] Narayanan V. and N. R, Organization Theory. A Strategic Approach. Homewood IL Boston: Richard D. Irwin Inc., 1993.

[14] Henry, N. Public Administration and Public Affairs. London: Prentice-Hall International, Inc, 1989.

[15] Rosenbloom, D. H. et al. Public Administration. Understanding Management, Politics, and Law in The Public Sector. Eighth Edition. New York: McGraw-Hill International Edition., 2015.

[16] Robbins, S. P. Organization Theory: Structure, Design, and Applications, Third Edition. Englewood Clifft New Jersey: Prentice-Hall International, Inc, 1990.

[17] Siagian, S. P. Filsafat Administrasi, Edisi Revisi. Jakarta: Bumi Aksara, 2008.

[18] Lubis, H. Organisasi. Jakarta: Universitas Terbuka.

[19] Boone L. E. and D. L. Kurtz, Contemporary Business. Mason, USA: Thomson South-Western, 2006.

[20] Griffin R. W. and R. J. Ebbert, Business, Eight Edition. New Jersey: Perason Education International, 2006.

[21] Pride, W. M., R. J. Hughes, and J. R. Kappor, Business, Twelfth Edition. Australia: South-Western Ceugage Learning, 2014.

[22] Rosenbloom, D. Contemporary Public Administration. New York: McGraw-Hill. Inc., 1994.

[23] Ranson S. and J. Stewart, Management for the Public Domain. Enabling the Learning Society. New York: St. Martin's Press, 1994.

[24] Keban, Y. T. Enam Dimensi Strategis Administrasi Publik. Konsep, Teori dan Isu. Yogyakarta: Gaya Media, 2004

[25] Dunn, W. N. Public Policy Analysis : An Introduction. London: Prentice-Hall International, Inc, 1981.

[26] MacRae Jr. D. and W. James, Policy Analysis for Public Decisions. New York: University Press of America, 1989.

[27] Anderson, J. E. Public Policy-Making, Second Edition. New York: Holt, Rinehart and Winston, 1978.

[28] Michael, E. J. Public Policy: The Competitive Framework. South Melbourne: Oxford University Press, 2006.

[29] Jones, C. O. An Introduction to the Study of Public Policy, Third Edition. California: Brooks/Cole Publishing Company, 1984.

[30] Marzuki, P. M. Penelitian Hukum, Edisi Revisi. Jakarta: Prenadamedia Group, 2015.

[31] Soekanto S. and S. Mamudji, Penelitian Hukum Normatif. Suatu Tinjauan Singkat. Jakarta: PT RajaGrafindo Persada, 2015.

[32] Howlett M. and M. Ramesh, Studying Public Policy. Policy Cycles and Policy Subsystems. Toronto: Oxford University Press, 1995.

[33] Hill, M. The Policy Process in the Modern State, Third Edition. London: Prentice-Hall International, Inc, 1997.

[34] Stillman II, R. J. Public Administration. Concepts and Cases. Ninth Edition. Australia: Wadsworth Cengage Learning, 2010.

[35] Bromley, D. W. Economic Interest and Institution. The Conceptual Foundation of Public Policy. New York: Basil Blackwell Inc, 1989. 